\title{
SOUTH AFRICA EXPORTS OF METAL AND ARTICLES OF BASE METAL: A GRAVITY MODEL APPROACH
}

\author{
J H Eita ${ }^{*}$ and A C Jordaan
}

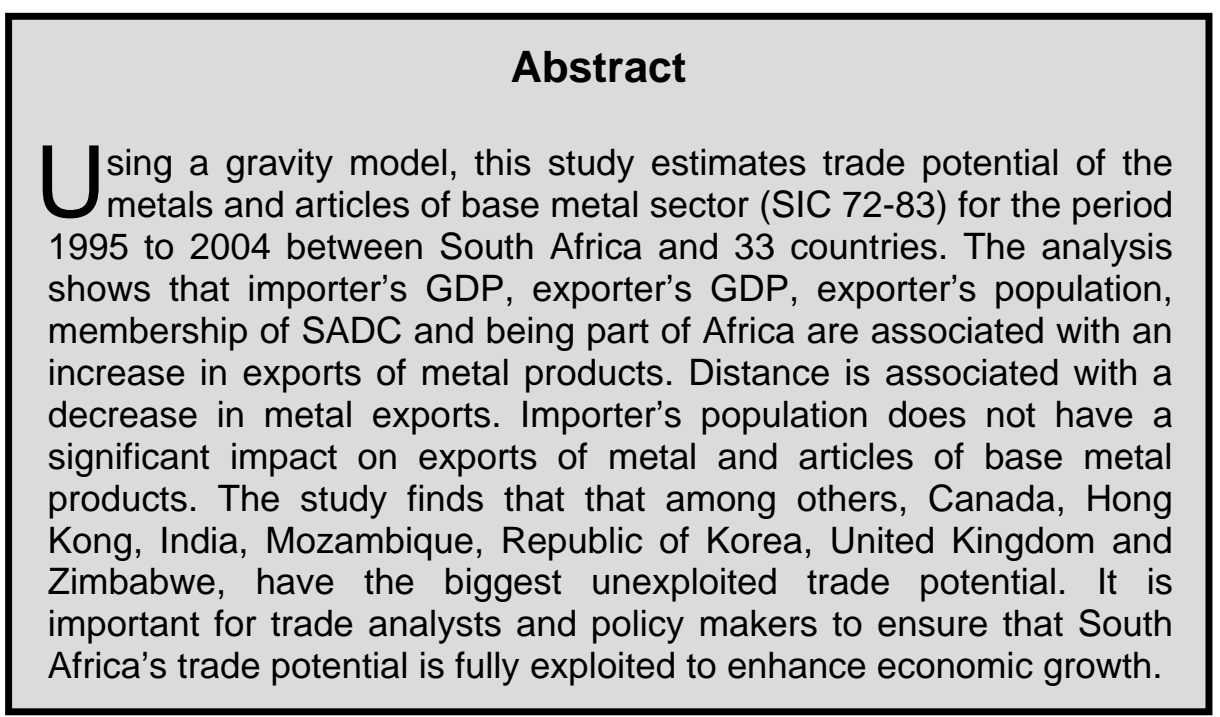

\section{Introduction}

Exports play an important role in the process of growth by generating scarce foreign exchange reserves that are necessary to finance imports of goods such as energy and investment goods. These goods are crucial for the formation of capital and economic growth. Exports ease the pressure on the balance of payments and create employment opportunities (Abou-Stait, 2005: 1). A growth strategy that is export-led provides incentives to producers to rather export their products. This increase the capability of producing goods and services that can compete in the world market using advanced technology which will provide foreign exchange needed to import goods and services. Exports can also reduce the impact of external shocks on the domestic economy. Abou-Stait (2005) noted that the experience of Latin American and Asian economies provides good examples of the importance of exports to economic growth. Senhadji and Montenegro (1999) also stressed the vital role of exports as an engine of economic growth.

\footnotetext{
* Department of Economics, University of Pretoria, Pretoria 0002, Republic of South Africa. Email: hinaeita@yahoo.co.uk and andre.jordaan@up.ac.za
} 
After the assumption of office in 1994 by the new democratically elected government, South Africa adopted an export-led based growth strategy, known as the Growth Employment and Redistribution (GEAR) strategy (Naude, Oostendorp and Serumaga-Zake, 2005: 108). Under this strategy, various measures were introduced in 1996 in order to promote exports. In 2005, under the Accelerated and Shared Growth Initiative-South Africa (ASGISA) the South African government identified priority sectors that need to be promoted and developed in order to accelerate growth and halve poverty and unemployment by 2014. Among these, the metals and articles of base metal sector was identified as a priority sector that needs to be developed for this purpose (The Presidency Republic of South Africa, 2006).

The metal sector is important in the South African economy as it contributes 4 percent to GDP. During the period 1995-2004 exports of metal and articles of base metal products accounted for 15 percent of South Africa's commodities exports. Given this importance and the role it plays in the economy, it is important to determine the trade potential to different countries. A gravity model is a useful tool in determining the trade or export potential of a country. The model has its foundations in physical sciences and proven to be a useful tool in the analysis of bilateral trade flows. The idea of explaining trade flows in analogy to Newton's law of gravity by the attraction of two countries' masses, weakened by distance between them and enforced by preferential trade agreements they belong to was pioneered by Tinbergen (1962) and Pöyhonen (1963). Countries' masses are measured by GDP or population, distance between countries measures transport costs. Like in physical science, the bigger and the closer the units are to each other, the stronger the attraction. The comparison with gravity derives from GDP being a proxy for economic mass and distance as a proxy for resistance.

The Gravity model is used to investigate the relationship between the volume and direction of international trade and the formation of regional trade blocks where members are in different stages of development. The gravity model is augmented with a number of variables to test whether they are relevant in explaining trade (Martine-Zarzoso \& Nowak-Lehmann, 2003: 292). These variables include GDP, distance, infrastructure endowments, differences in per capita income and real exchange rates.

The objective of this paper is to investigate the factors determining exports of metal products and articles of base metals (SIC 72-83) using the gravity model. The study also investigates whether there is unexploited trade potential among South Africa's trading partners. The rest of the paper is organised as follows. Section 2 discusses the gravity model; Section 3 describes the estimation procedure; Section 4 deals with the univariate characteristics of the data, and Section 5 presents the estimation results. Potential trade is discussed in Section 6 while the conclusion is provided in Section 7. 


\section{The gravity model}

The gravity model was first applied to international trade in the early 1960s. Among others, Pöyhönen (1963) was the first to apply the gravity model to international trade. In the latter half of the twentieth century, the gravity model has been used to explain migration and other social flows in terms of gravitational forces of human interaction. Like in physical science, the bigger and closer the units are to each other, the stronger the attraction. The comparison with gravity derives from gross domestic product (GDP) being a proxy for economic mass and distance a proxy for resistance.

The gravity model performed well in analysing the international trade flows in the early 1960s but strong theoretical foundations were not produced until the end of the 1970s. This led to many studies to modify the original Newtonian gravity equation. From the works of Anderson (1979) and Bergstrand (1985, 1989) it became clear that the gravity equation is a good representation irrespective of the structure of product markets. Bergstrand $(1985,1989)$ included population size while Oguledo and Macphee (1994) included price variables.

Oguledo and Macphee (1994) derived the gravity equation from a linear expenditure system. This was in an attempt to answer criticism that the theoretical foundation of the gravity model is weak. The analysis assumes a weakly separable utility function from which a linear expenditure could be derived (Oguledo and Macphee, 1994: 112).

In its general form, exports from country $i$ to country $j$ are explained by their economic sizes (GDP), population, geographical distance and a set of dummies incorporating some kind of institutional characteristics common to specific flows. The basic model is specified as (Martinez-Zarzoso and Nowak-Lehmann, 2003: 296; Jakab, Kovács and Oszlay, 2001: 280):

$$
X_{i j}=\beta_{0} Y_{i}^{\beta_{1}} Y_{j}^{\beta_{2}} N_{i}^{\beta_{3}} N_{j}^{\beta_{4}} D_{i j}^{\beta_{5}} A_{i j}^{\beta_{0}} u_{i j}
$$

where

$\mathrm{X}_{\mathrm{ij}}$ is export of goods by country $\mathrm{i}$ to country $\mathrm{j}, \mathrm{Y}_{\mathrm{i}}$ and $\mathrm{Y}_{\mathrm{j}}$ are the GDP of the exporter and importer, $\mathrm{N}_{\mathrm{i}}$ and $\mathrm{N}_{\mathrm{j}}$ are the populations of the exporter and importer, $D_{i j}$ is the distance between the two countries, $A_{i j}$ represents any other factors influencing trade between the countries and $\mathrm{u}_{\mathrm{ij}}$ is the error term. For the purpose of estimation, the model in Equation (1) is expressed in log form as:

$$
\ln \mathrm{X}_{\mathrm{ij}}=\beta_{0}+\beta_{1} \ln \mathrm{Y}_{\mathrm{i}}+\beta_{2} \ln \mathrm{Y}_{\mathrm{j}}+\beta_{3} \ln \mathrm{N}_{\mathrm{i}}+\beta_{4} \ln \mathrm{N}_{\mathrm{j}}+\beta_{5} \ln \mathrm{D}_{\mathrm{ij}}+\ln \beta_{6} \ln \mathrm{A}_{\mathrm{ij}}+\mathrm{u}_{\mathrm{ij}} \ldots
$$

A high level of GDP indicates a high level of production in the exporting country which increases the availability of exports, and a high level of income in the 
importing country suggests high imports, hence $\beta_{1}$ and $\beta_{2}$ have positive signs. The coefficient estimate for population of the exporting country (South Africa) can be positive or negative depending on whether the country export more when it is large in economic terms or whether a large country export less than the smaller one. The population coefficient of the importing country can also be positive or negative for similar reasons (see Martinez-Marzoso and Nowak-Lehman, 2003: 297). That means $\beta_{3}$ and $\beta_{4}$ have ambiguous signs. This is also supported by Oguledo and MacPhee (1994: 114) that the effect of the population variables (for importing and exporting country) on trade is indeterminate. Population size can be tradeenhancing as well as trade-inhibiting. A large population on one hand may indicate large resource endowment, self sufficiency and less reliance on international trade. It is possible on the other hand that a large domestic market or population promotes division of labour and thus creates opportunities for trade in a wide variety of goods, and in this case the coefficient of the population variables can be positive. The coefficient of distance is expected to be negative because it is a proxy for transport costs ( $\beta_{5}$ is expected to be negative).

This study introduces dummy variables to represent countries which are members of the Southern African Development Community (SADC) or part of the African continent in order to test the impact of regional agreements on bilateral exports. Countries that are part of the African continent or members of SADC are coded one and zero otherwise. After introducing the dummy variables Equation (2) is respecified as:

$$
\begin{aligned}
\ln \mathrm{X}_{\mathrm{ijt}}= & \alpha_{\mathrm{ij}}+\beta_{1} \ln \mathrm{Y}_{\mathrm{it}}+\beta_{2} \ln \mathrm{Y}_{\mathrm{jt}}+\beta_{3} \ln \mathrm{N}_{\mathrm{it}}+\beta_{4} \ln \mathrm{N}_{\mathrm{jt}}+\beta_{5} \ln \mathrm{D}_{\mathrm{ij}}+ \\
& \beta_{6} \mathrm{SADC}+\beta_{7} \text { AFRICA }+\mathrm{u}_{\mathrm{ijt}}
\end{aligned}
$$

where

$\alpha_{\mathrm{ij}}$ represents individual effects, $S A D C$ is the dummy variable taking the value of 1

if the country is a member of SADC and 0 otherwise, and AFRICA is the dummy variable for countries that are part of the African continent and takes the value of 1 if part of African continent, or 0 otherwise. According to Carrère (2006) membership of regional groupings can generate a significant increase in trade. The coefficients of SADC and African continent dummies are thus expected to be positive.

\section{Estimation procedure}

Different models can be estimated in panel estimation. These models are pooled, fixed effects and random effects. Since individual effects are included in the regressions a decision should be made whether they are treated as random or fixed. A random effects model can be more appropriate when estimating the flows of trade between a randomly drawn sample of trading partners from a large population. A fixed effects model would be a better model when estimating the flows of trade between an ex ante predetermined selection of countries (see Egger, 
2000: 26). Since this study deals with the flows of trade between South Africa and 33 main trading partners, the fixed effect will be a more appropriate model than the random effect specification. The top 33 trading partners were selected based on trade statistics (metal and articles of base metal) for the period 2000 to 2004. Furthermore, the study also applies the Hausman test to check whether the fixed effects model is more efficient than the random effects model. This will be true if the null hypothesis of no correlation between the individual effects and the regressors is rejected.

One problem with a fixed effects model is that variables that do not change over time cannot be estimated directly because the inherent transformation wipes out such variables. These variables as Martinez-Zarzoso and Nowak-Lehman (2001: 299) stated can be estimated in a second step by running another regression with the individual effects as the dependent variable and distance and dummies as explanatory variables. This is estimated as:

$$
\mathrm{IE}_{\mathrm{ij}}=\alpha_{0}+\alpha_{1} \mathrm{D}_{\mathrm{ij}}+\alpha_{2} \text { AFRIDUM }+\alpha_{3} \operatorname{SADCDUM}+\mu_{\mathrm{i}}
$$

where

$\mathrm{IE}_{\mathrm{ij}}$ denotes individual effects, $\mathrm{D}_{\mathrm{ij}}$ is distance, AFRIDUM and SADCDUM are dummy variables taking the value of one when a country is part of the African continent or member of the Southern African Development Community (SADC) respectively and zero otherwise.

\section{Univariate characteristics of variables}

Prior to estimating Equation (3), the study analysed the univariate characteristics of the data which entails panel unit root tests. Unit root test is the first step in determining a potentially cointegrated relationship between the variables. If all variables are stationary, then the traditional estimation methods can be used to estimate the relationship between the variables. If the variables are nonstationary a test for cointegration is required. There are different types of panel unit roots tests. The first test is the one of Levin, Lin and Chu (2002) and the second is that of Hadri (2000). The two tests of panel unit roots assume that the autoregressive parameters are common across countries. Levin, Lin and Chu (2002) which is also referred to as LLC uses a null hypothesis of a unit root, while that of Hadri (2000) uses a null of no unit root.

A third test is referred to as the IPS test developed by Im, Pesaran and Shin (2003). It allows the autoregressive parameters to vary across countries and also for individual unit root processes. It is computed by combining individual countries' unit root tests in order to come up with a result that is specific to a panel. It has more power than the single-equation Augmented Dickey Fuller (ADF) by averaging N independent ADF regressions (Straus and Yigit, 2003: 309). The ADF tests specification may include an intercept but no trend or may include an intercept and time trend. The null hypothesis is that all series contain a unit root and the 
alternative is that at least one series in the panel contain a unit root. IPS is a onetailed or lower tailed test based on the $\mathrm{N}(0,1)$ distribution. The IPS and LLC are applied in this study and test results are presented in Table A1 in the Appendix. The IPS test results show that variables are stationary with the exception of exports and importer's population. The LLC test results indicate that all variables are stationary (null of unit root is rejected). The study uses rejection of unit root by at least one test to assume a verdict of stationarity. This implies that cointegration test is not required and ordinary least squares method can be used to estimate Equation (3)

\section{Estimation results}

The estimation results for the pooled, fixed effects and random effects models are presented in Table 1. The results in the second column of Table 1 are those of the pooled panel data model. The problem with this model is that it does not allow for heterogeneity of countries, and no country specific effects are estimated. It assumes that all countries are homogenous.

The third column presents the results of the fixed effects model. The fixed effects model introduces heterogeneity by estimating country specific effects. The F-test was performed to check the poolability of the data. The pooled model is the restricted model with the assumption of a single intercept $\left(\alpha_{i j}=\alpha\right)$ and same parameters over time and across trading partners. The unrestricted model allows an intercept and other parameters to vary across trading partners. The result of the Ftest shows that the null hypothesis of equality of the individual effects is rejected. This implies that a model with individual effects must be selected.

Finally, the results in column 4 are those of the random effects model. The random effects model also acknowledges heterogeneity in the cross section, but it differs from the fixed effects model in the sense that it assumes that the effects are generated by a specific distribution. It assumes differences in the cross section but does not model each effect explicitly. It avoids the loss of degrees of freedom which occurs in fixed effects. The LM test for random effects again rejects the null of no cross section heterogeneity in favour of the random effect specification.

The Hausman specification test is used to test the null hypothesis that the regressors and individual effects are not correlated in order to discriminate between the fixed effects model and random effects model. If the null hypothesis is accepted the random effect will be preferred, but if the null hypothesis is rejected the fixed effects model will be preferred. The result of the Hausman test shows that the null is rejected, indicating that the country specific effects are correlated with regressors. This implies that the fixed effect model is appropriate since random effects estimates are not consistent. 
Table 1: Estimation results

\begin{tabular}{l|l|l|l}
\hline \multicolumn{1}{c|}{ Variables } & \multicolumn{1}{c|}{ Pooled model } & \multicolumn{1}{c}{ Fixed effects model } & \multicolumn{1}{c}{$\begin{array}{c}\text { Random effects } \\
\text { model }\end{array}$} \\
\hline Constant & $-102,436(-3,955)^{* * *}$ & $-102,737(-6,062)^{* * *}$ & $-101,860(-6,139)^{* * *}$ \\
\hline Importer's GDP & $0,684(13,237)^{* * *}$ & $0,830(3,702)^{* * *}$ & $0,712(5,890)^{* * *}$ \\
\hline South Africa's GDP & $0,771(1,637)$ & $0,736(2,465)^{* * *}$ & $0,761(2,607)^{* * *}$ \\
\hline $\begin{array}{l}\text { Importer's } \\
\text { population }\end{array}$ & $-0,125(-2,82)^{* * *}$ & $-0,971(-1,012)$ & $-0,146(-1,228)$ \\
\hline $\begin{array}{l}\text { South Africa's } \\
\text { population }\end{array}$ & $5,179(5,23)^{* * *}$ & $5,534(6,227)^{* * *}$ & $5,146(8,120)^{* * *}$ \\
\hline $\begin{array}{l}\text { Distance in } \\
\text { kilometres }\end{array}$ & $-0,693(-4,156)^{* * *}$ & & $-0,706(-1,531)$ \\
\hline $\begin{array}{l}\text { African continent } \\
\text { dummy }\end{array}$ & $0,613(2,322)^{* * *}$ & & $0,697(0,986)$ \\
\hline $\begin{array}{l}\text { SADC dummy } \\
\text { Adjusted R-squared }\end{array}$ & $0,205(0,737)$ & 0,82 & $0,192(0,248)$ \\
$\begin{array}{l}\text { F-test } \\
\text { LM test }\end{array}$ & 0,47 & $17,58 * *$ & 0,768 \\
\hline Hausman test & $797,283^{* * *}$ & $566,319 * * *$ \\
\hline
\end{tabular}

Notes: $* * * / * * / *$ significant at $1 \% / 5 \% / 10 \%$ level.

t-statistics are in parentheses.

Source: Authors own estimates: EViews 5.

The results of the fixed effect model in Table 1 show that an increase in the GDP of the importing country leads to an increase in South Africa's exports of metal products. This is consistent with the theoretical expectation. The coefficient of South Africa's GDP also has a positive and significant coefficient. This indicates that an increase in South Africa's GDP has a significant positive impact on the exports of metal products.

The population of South Africa has a significant positive effect on the export of metal and articles of base metal products. The positive coefficient implies that South Africa exports more when it grows because of economies of scale. This is consistent with theoretical expectation. However, population of the importing country has an insignificant negative effect on the export of the metal products. The negative coefficient of the importing country's population is consistent with the theoretical expectation as mentioned in Section 2. This negative and insignificant coefficient is comparable to that obtained among others, by Sapir (1981). Studies by Aitken (1973) and Bikker (1987) found a negative and significant coefficient for population of the importing country.

Estimates for country specific effects are presented in Table A2 of the Appendix. Country specific effects show the effects or factors which are unique to each country but not included in the gravity model. They emphasise that the bilateral trade in metal products between South Africa and its trading partners differs from country to country and that each country is unique. The results in Table A2 show that there are unique characteristics in some countries that encourage trade between South Africa's exports of metals to Angola, Brazil, China, Ghana, India, Italy, Japan, Kenya, Republic of Korea, Malaysia Mozambique, Nigeria, Thailand, Tanzania, USA, Zambia and Zimbabwe (the shaded fixed effects). The results also 
show that there are unobservable country characteristics that discourage South Africa's export of metal products to Australia, Belgium, China, France, Germany, Hong Kong, Netherlands, Spain, Switzerland, Saudi Arabia, Singapore, Sweden, United Kingdom and United Arab Emirates (negative signs). It is important to investigate factors which hinder the exports of metal products to the countries not shaded or with negative signs in Table A2. This is important for policy formulation.

Some factors which may explain the fixed effects in Table A2 are determined in the second stage regression. These are factors which for example contribute to the positive country specific effects in Angola or to the negative country-specific effects in Australia. The results of the second stage regression are presented in Table 2. Distance has a negative and significant coefficient, and this in consistent with the theoretical expectation. The dummy variables have positive and significant coefficients as expected a priori. South Africa exports more metals to SADC and other African countries.

Table 2: Second stage regression: individual effects regressed on distance and dummies

\begin{tabular}{l|c}
\hline \multicolumn{1}{c|}{ Independent variables } & Coefficient (t-statistics) \\
\hline Constant & $0,309(0,871)$ \\
\hline Distance & $-0,081(-2,183)^{* * *}$ \\
\hline African continent dummy & $1,412(17,682)^{* * *}$ \\
\hline SADC dummy & $0,490(5,797)^{* * *}$ \\
\hline Adjusted R-squared & 0,988 \\
\hline
\end{tabular}

$* * *$ Significant at $1 \%$

Source: Authors own estimates: EViews 5

\section{Potential trade}

The estimated fixed effects model of Equation (3) is solved to determine within sample potential exports of metal products (see Nilsson, 2000; Brulhart and Kelly, 1999). Potential exports are compared to actual exports in order to determine if there is trade potential which is not exploited. Actual and potential exports are plotted in Figure 1. Among others, Canada, Hong Kong, India, Mozambique, Republic of Korea, United Kingdom, and Zimbabwe have the biggest trade potential relative to other countries. Detailed data on the comparison between actual exports and potential exports as well as export ratio are presented in Table A3 in the Appendix. Shaded cells are for trading partners with unexploited trade potential (actual export is below potential export). 

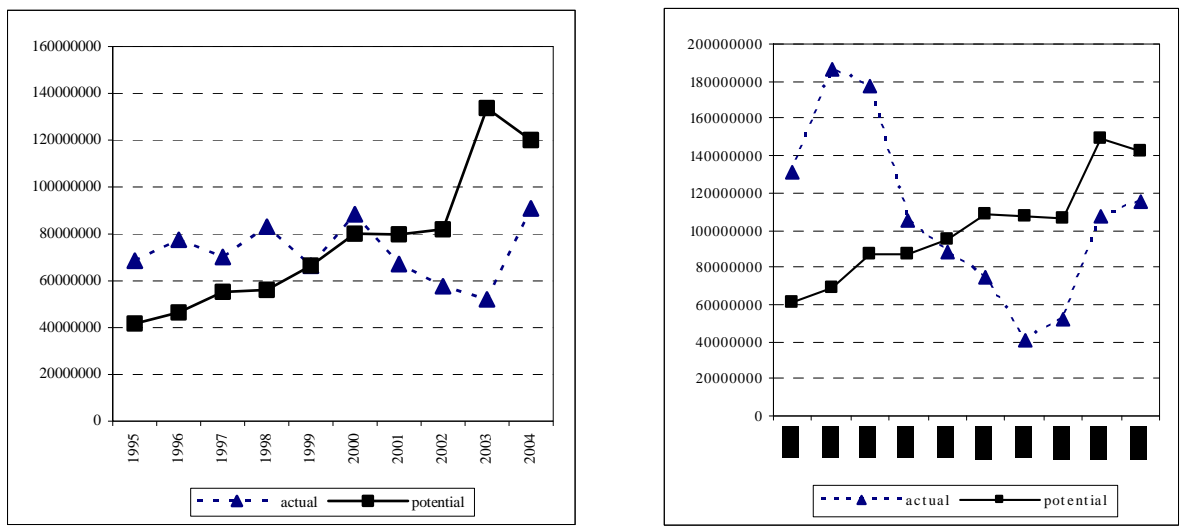

India

Mozambique
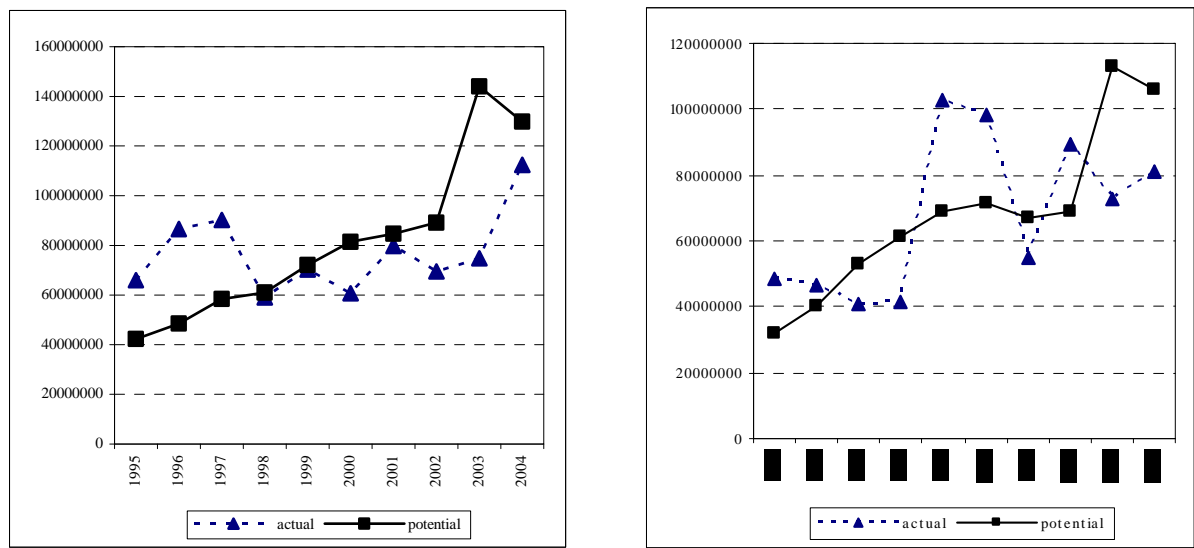

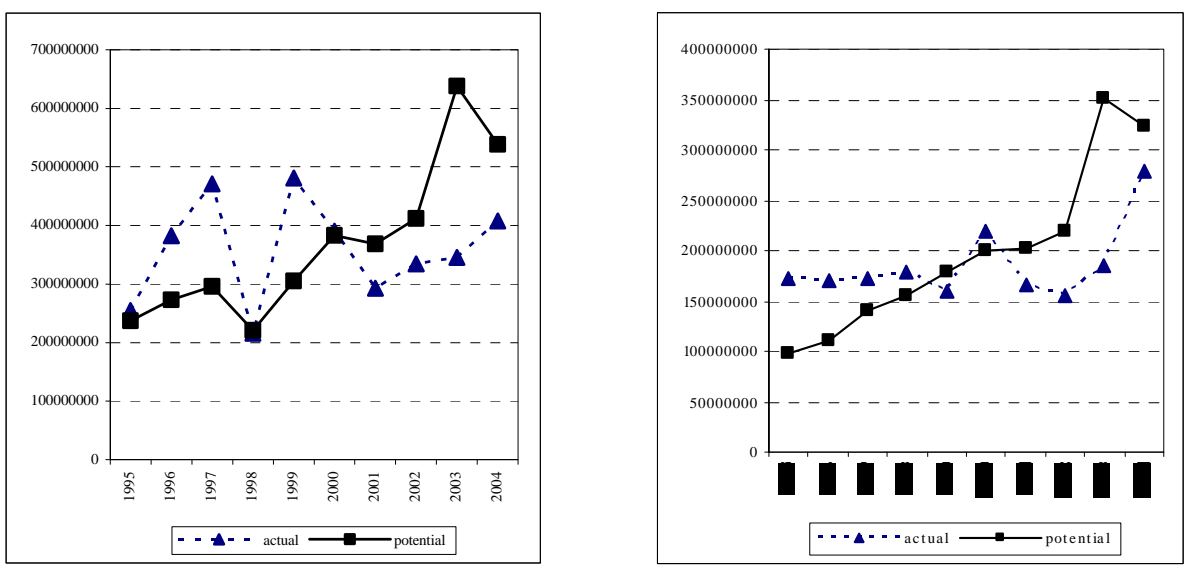

\section{Zimbabwe}

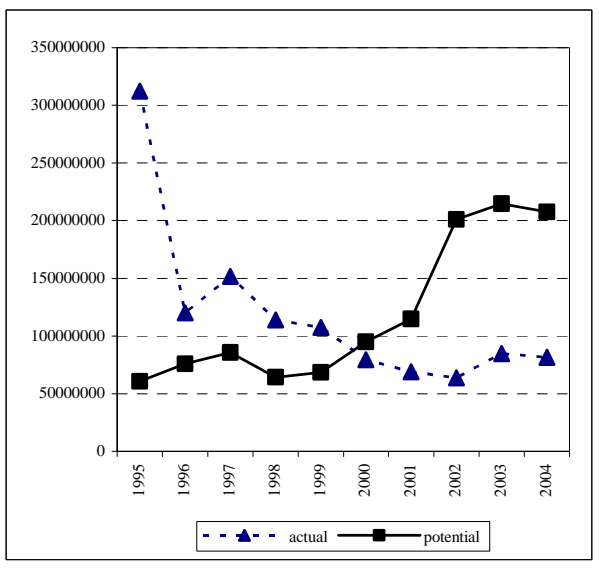

Figure 1:Actual and potential exports of South Africa's metal products (in USA dollars)

\section{Conclusion}

This study applied the gravity model to South Africa's annual export of metal products for the period 1995 to 2004 in order to analyse the factors which determine trade flows between South Africa and its trading partners. The model was estimated for 33 main trading partners, investigating whether there is unexploited trade potential. The study found that an increase in the importer's GDP and South Africa's GDP cause an increase in export. Importer's population 
does not have a serious impact on the exports, while South Africa's population has a positive and significant impact on export. This suggests that South Africa exports more when its own population increases (economies of scale).

In line with theoretical expectations, distance has a negative effect on exports. The further the country is from South Africa, the lower the export and this is probably because of increase in transport costs. Finally, membership of SADC and being part of the African continent seems to promote exports.

The gravity equation was solved to determine the potential export. This is important especially if the export market is not certain. The study found that among others, Canada, Hong Kong, India, Mozambique, Republic of Korea, United Kingdom, and Zimbabwe, have the biggest trade potential in metals relative to other trading partners. The results of the study is important for trade policy analysts and other policy makers to ensure that South Africa's trade potential is fully exploited to enhance economic growth.

\section{References}

Abou-Stait, F (2005): “Are Exports the Engine of Economic Growth? An Application of Cointegration and Causality Analysis for Egypt, 1977-2003”, Economic Research Working Paper Series, No. 76, Tunisia: African Development Bank.

Aitken, N D (1973): "The Effect of the EEC and EFTA on European Trade: A temporal cross-section Analysis”, American Economic Review, 63(5), 881-892.

Anderson, J E (1979): “A Theoretical Foundation for the Gravity Equation”, American Economic Review, 69(1), 106-116.

Bergstrand, J H (1985): "The Gravity Equation in International Trade: Some Microeconomic Foundations and Empirical Evidence”, Review of Economics and Statistics, 67(3), 474-480.

Bergstrand, J H (1989): “The Generalised Gravity Equation, Monopolistic Competition and the FactorProportions Theory in International Trade”, Review of Economics and Statistics, 71(1), 143-153.

Bikker, J A (1987): “An International Trade Flow with Substitution: An Extension of the Gravity Model”, KYKLOS, 40(3), 315-737.

Blülhart, M and Kelly, M J (1999): "Ireland's Trading Potential with Central and Eastern European Countries: A Gravity Study”, The Economic and Social Review, 30(2), 159-174.

Carrère, C (2006): "Revisiting the Effects of Regional Trade Agreements on Trade Flows with Proper Specification of the Gravity Model”, European Economic Review, 50, 223-247.

Egger, P (2000): “A Note on the Proper Econometric Specification of the Gravity Equation”, Economic Letters, 66, 25-31.

Hadri, K (2000): “Testing for Stationarity in Heterogeneous Panel Data”, Econometric Journal, 3(2), $148-161$.

Im, K S, Pesaran, M H and Shin, Y (2003): “Testing for Unit Roots in Heterogeneous Panels”, Journal of Econometrics, 115, 53-74. 
Jakab, Z M, Kovacs, M A and Oszlay, A (2001): "How Far has Regional Integration Advanced?: An Analysis of the Actual and Potential Trade of Three Central and European Countries”, Journal of Comparative Economics, 29, 276-292.

Levin, A, Lin, C F and Chu, C (2002): “Unit Roots Tests in Panel Data: Asymptotic and Finite Sample Properties”, Journal of Econometrics, 108, 1-24.

Martinez-Zarzoso, I and Nowak-Lehmann, F (2003): “Augmented Gravity Model: An Empirical Application to Mercosur-European Union Trade Flows”, Journal of Applied Economics, 6(2), 291-316.

Naude, W A, Oostendorp, R and Serumaga-Zake, P (2005): "Determinants of Manufacturing Exports: Results from a Regional Firm-Level Survey in South Africa”, Journal of Studies in Economics and Econometrics, 29(2), 108-116.

Nilsson, L (2000): “Trade Integration and the EU Economic Membership Criteria”, European Journal of Political Economy, 16, 807-827.

Oguledo, V I and Macphee, C R (1994): “Gravity Models: A Reformulation and an Application to Discriminatory Trade Arrangements”, Applied Economics, 26, 107-120.

Pöyhönen, P (1963): “A Tentative Model for the Volume of Trade Between Countries”, Weltwirtschaftliches Archiv, 90, 93-99.

Presidency Republic of South Africa (2006): Accelerated and Shared Growth Initiative - South Africa (ASGISA), Pretoria: Presidency Republic of South Africa.

Sapir, A (1981): “Trade Benefits Under EEC Generalised System of Preferences”, European Economic Review, 15(3), 339-355.

Senhadji, A S and Montenegro, C E (1999): "Time Series Analysis of Export Demand Equations: A Cross-Country Analysis”, IMF Staff Papers, 46(3), 259-273.

Strauss, J and Yigit, T (2003): “Shortfalls of Panel Unit Root Testing”, Economic Letters, 81, 309-313.

Tinbergen, J (1962): Shaping the World Economy. Suggestion for an International Economic Policy, New York: The Twentieth Century Fund. 


\section{Appendix}

Data

The estimation covers the period 1995 to 2004. Thirty three countries are included in the estimation. The data for exports are sourced from Quantec Research at: http://ts.easydata.co.za. The data for GDP and population are taken from the World Bank's World Development Indicators. Distance data are collected from http://www.indo.com/distance/. Estimates done by authors in EViews 5.

Table A1: Panel unit root test

\begin{tabular}{l|c|c}
\hline Variable & $\begin{array}{l}\text { IPS test statistic } \\
\text { Null: all series in panel } \\
\text { contain a unit root }\end{array}$ & $\begin{array}{l}\text { LLC test statistics } \\
\text { Null: unit root (common } \\
\text { unit root process) }\end{array}$ \\
\hline Export & $1,278(0,899)$ & $-2,279(0,011)^{* * *}$ \\
\hline Importer's GDP & $-1,328(0,09)^{*}$ & $-4,352(0,000)^{* * *}$ \\
\hline Importer's population & $3,568(0,999)$ & $-6,387(0,000)^{* * *}$ \\
\hline South Africa's population & $-13,129(0,00)^{* * *}$ & $-9,648(0,000)^{* * *}$ \\
\hline South Africa's GDP & $-5,635(0,000)^{* * *}$ & $-14,369(0,000)^{* * *}$ \\
\hline $\begin{array}{l}\text { Notes: ***/**/* rejection of the null at } 1 \% / 5 \% / 10 \% . \\
\text { Probabilities are in parentheses }\end{array}$
\end{tabular}

Table A: Fixed effects for the metal products

$\begin{array}{lc}\text { ANGOLA } & 0,38915 \\ \text { AUSTRALIA } & -1,25576 \\ \text { BELGIUM } & -1,36423 \\ \text { BRAZIL } & 0,047097 \\ \text { CANADA } & -1,18986 \\ \text { CHINA } & 2,189813 \\ \text { FRANCE } & -1,05006 \\ \text { GHANA } & 0,923505 \\ \text { GERMANY } & -0,64902 \\ \text { HONG KONG } & -1,16041 \\ \text { INDIA } & 2,591798 \\ \text { ITALY } & 0,11284 \\ \text { JAPAN } & 0,689955 \\ \text { KENYA } & 1,921834 \\ \text { REPUBLIC OF KOREA } & 1,063518 \\ \text { MEXICO } & -0,46534 \\ \text { MALAYSIA } & 0,22202 \\ \text { MOZAMBIQUE } & 2,526335 \\ \text { NIGERIA } & 0,943367 \\ \text { NETHERLANDS } & -0,36431 \\ \text { SPAIN } & -0,67065 \\ \text { SWITZERLAND } & -3,0125 \\ \text { SAUDI ARABIA } & -1,14936 \\ \text { SINGAPORE } & -1,96017\end{array}$




$\begin{array}{lc}\text { SWEDEN } & -3,28253 \\ \text { UNITED KINGDOM } & -0,2292 \\ \text { THAILAND } & 1,218533 \\ \text { TANZANIA } & 1,32275 \\ \text { USA } & 0,758529 \\ \text { VIETNAM } & -0,61841 \\ \text { ZAMBIA } & 1,666985 \\ \text { ZIMBABWE } & 1,928748 \\ \text { UNITED ARAB } & \\ \text { EMIRATES } & -2,09497\end{array}$

Note: shaded cells are positive country specific effects

Table A3: Actual and potential exports

\begin{tabular}{|c|c|c|c|c|}
\hline & & 2002 & 2003 & 2004 \\
\hline \multirow[t]{3}{*}{ Angola } & Actual & 32400159,1 & 51609922,1 & 80672246,9 \\
\hline & Potential & 29249703,7 & 46417634,6 & 41681168,9 \\
\hline & Export ratio & 0,9027642 & 0,89939362 & 0,51667296 \\
\hline \multirow[t]{3}{*}{ Australia } & Actual & 66928100,9 & 90063161,8 & 124863821 \\
\hline & Potential & 75160771,7 & 130370376 & 107698908 \\
\hline & Export ratio & 1,12300769 & 1,44754384 & 0,86253093 \\
\hline \multirow[t]{3}{*}{ Belgium } & Actual & 44415705 & 76515379,7 & 184533443 \\
\hline & Potential & 82196230,4 & 139536950 & 113341960 \\
\hline & Export ratio & 1,85061186 & 1,82364579 & 0,61420823 \\
\hline \multirow[t]{3}{*}{ Brazil } & Actual & 39412116 & 49987750,8 & 82896747,1 \\
\hline & Potential & 36658650,9 & 54811468 & 44282937,4 \\
\hline & Export ratio & 0,93013658 & 1,09649798 & 0,53419391 \\
\hline \multirow[t]{3}{*}{ Canada } & Actual & 57607813,1 & 51969504,9 & 90860833,3 \\
\hline & Potential & 81984437,4 & 133714836 & 119984125 \\
\hline & Export ratio & 1,42314789 & 2,57294804 & 1,32052635 \\
\hline \multirow[t]{3}{*}{ China } & Actual & 130350632 & 400245417 & 390229357 \\
\hline & Potential & 104713646 & 163100968 & 153548955 \\
\hline & Export ratio & 0,80332288 & 0,4075024 & 0,39348386 \\
\hline \multirow[t]{3}{*}{ France } & Actual & 78170353,3 & 85857897,2 & 146422536 \\
\hline & Potential & 89346265,3 & 150526544 & 123083064 \\
\hline & Export ratio & 1,14296868 & 1,75320558 & 0,84060191 \\
\hline \multirow[t]{3}{*}{ Germany } & Actual & 130948406 & 234042364 & 394184921 \\
\hline & Potential & 127035864 & 212978121 & 168130328 \\
\hline & Export ratio & 0,9701215 & 0,90999816 & 0,42652653 \\
\hline \multirow[t]{3}{*}{ Ghana } & Actual & 12713003,1 & 40807441 & 55434348 \\
\hline & Potential & 19828483,1 & 33297737,2 & 26246153,4 \\
\hline & Export ratio & 1,55970096 & 0,81597219 & 0,47346373 \\
\hline \multirow[t]{3}{*}{ Hong Kong } & Actual & 52342445,1 & 107265813 & 115655261 \\
\hline & Potential & 106513255 & 149309218 & 142680725 \\
\hline & Export ratio & 2,03493083 & 1,3919553 & 1,23367258 \\
\hline
\end{tabular}




\begin{tabular}{|c|c|c|c|c|}
\hline India & Actual & 69541980,2 & 74763904,8 & 112391321 \\
\hline & Potential & 89118722,6 & 143995125 & 129752585 \\
\hline & Export ratio & 1,28150971 & 1,92599791 & 1,15447157 \\
\hline \multirow[t]{3}{*}{ Italy } & Actual & 192221734 & 298367701 & 419017193 \\
\hline & Potential & 251167348 & 429597809 & 359264700 \\
\hline & Export ratio & 1,30665426 & 1,43982679 & 0,85739847 \\
\hline \multirow[t]{3}{*}{ Japan } & Actual & 504348497 & 724880760 & 915865493 \\
\hline & Potential & 564968198 & 862917804 & 757443875 \\
\hline & Export ratio & 1,12019407 & 1,19042724 & 0,82702524 \\
\hline \multirow[t]{3}{*}{ Kenya } & Actual & 64361782,1 & 101569002 & 177983600 \\
\hline & Potential & 62318569,2 & 100299373 & 88001991,2 \\
\hline & Export ratio & 0,96825425 & 0,98749983 & 0,49443876 \\
\hline \multirow[t]{3}{*}{ Malaysia } & Actual & 71040606,2 & 100737035 & 176819119 \\
\hline & Potential & 79970630 & 120737581 & 102952678 \\
\hline & Export ratio & 1,12570309 & 1,19854213 & 0,58224856 \\
\hline \multirow[t]{3}{*}{ Mexico } & Actual & 42570625,9 & 50268510,2 & 79199087,1 \\
\hline & Potential & 49655017,5 & 68093342,1 & 71939065,1 \\
\hline & Export ratio & 1,16641502 & 1,3545924 & 0,908332 \\
\hline \multirow[t]{3}{*}{ Mozambique } & Actual & 89505869,3 & 72988342,2 & 81356150,2 \\
\hline & Potential & 69228279,5 & 113256985 & 106046687 \\
\hline & Export ratio & 0,77344961 & 1,55171335 & 1,30348704 \\
\hline \multirow[t]{3}{*}{ Netherlands } & Actual & 163429022 & 225947591 & 321314615 \\
\hline & Potential & 226095944 & 380634441 & 316549441 \\
\hline & Export ratio & 1,38345039 & 1,68461385 & 0,98516976 \\
\hline \multirow[t]{3}{*}{ Nigeria } & Actual & 28552238 & 66160805,3 & 120589375 \\
\hline & Potential & 17485281 & 29426906,5 & 26287655,1 \\
\hline & Export ratio & 0,61239616 & 0,44477854 & 0,21799313 \\
\hline \multirow{3}{*}{$\begin{array}{l}\text { Republic of } \\
\text { Korea }\end{array}$} & Actual & 334609035 & 345838946 & 407533901 \\
\hline & Potential & 411619526 & 637815746 & 538274925 \\
\hline & Export ratio & 1,23015066 & 1,84425656 & 1,32081018 \\
\hline \multirow[t]{3}{*}{ Saudi Arabia } & Actual & 30075259 & 40481791,2 & 93908661,3 \\
\hline & Potential & 39659457,4 & 61439284,4 & 56190597,7 \\
\hline & Export ratio & 1,31867385 & 1,51770173 & 0,59835373 \\
\hline \multirow[t]{3}{*}{ Singapore } & Actual & 22901086 & 35059092 & 60353206,1 \\
\hline & Potential & 46979880,8 & 67842540,7 & 60063326,2 \\
\hline & Export ratio & 2,0514259 & 1,93509121 & 0,99519694 \\
\hline \multirow[t]{3}{*}{ Spain } & Actual & 65947112,3 & 115404073 & 138394827 \\
\hline & Potential & 97880705,1 & 171254275 & 142348666 \\
\hline & Export ratio & 1,48423034 & 1,48395347 & 1,02856927 \\
\hline \multirow[t]{3}{*}{ Sweden } & Actual & 14310587 & 36132104,2 & 78181552 \\
\hline & Potential & 13746296,5 & 23619896,8 & 19364073 \\
\hline & Export ratio & 0,96056832 & 0,65370942 & 0,24768085 \\
\hline Switzerland & Actual & 39348573,1 & 43217518 & 64884515,3 \\
\hline
\end{tabular}




\begin{tabular}{|c|c|c|c|c|}
\hline & Potential & 24403570,2 & 39384779,8 & 31960457,7 \\
\hline & Export ratio & 0,62018946 & 0,91131517 & 0,4925745 \\
\hline \multirow[t]{3}{*}{ Tanzania } & Actual & 25485811,9 & 50064974 & 85871305,9 \\
\hline & Potential & 25415505,5 & 37276736,4 & 36697529,7 \\
\hline & Export ratio & 0,99724135 & 0,74456718 & 0,42735497 \\
\hline \multirow[t]{3}{*}{ Thailand } & Actual & 128947919 & 136937707 & 265198214 \\
\hline & Potential & 111392438 & 175109141 & 132188567 \\
\hline & Export ratio & 0,86385604 & 1,27875035 & 0,49845195 \\
\hline \multirow{3}{*}{$\begin{array}{l}\text { United Arab } \\
\text { Emirates }\end{array}$} & Actual & 22060487,9 & 53063033,2 & 86788912 \\
\hline & Potential & 37879855,1 & 54672423,5 & 52991919,6 \\
\hline & Export ratio & 1,71709054 & 1,03032978 & 0,61058398 \\
\hline \multirow[t]{3}{*}{ United Kingdom } & Actual & 154872290 & 184812421 & 278416291 \\
\hline & Potential & 218708423 & 350534609 & 323267270 \\
\hline & Export ratio & 1,41218564 & 1,89670481 & 1,16109323 \\
\hline \multirow[t]{3}{*}{ USA } & Actual & 431377088 & 502091479 & 1011041091 \\
\hline & Potential & 609707566 & 901544535 & 869709669 \\
\hline & Export ratio & 1,41339812 & 1,79557824 & 0,86021199 \\
\hline \multirow[t]{3}{*}{ Vietnam } & Actual & 28576170 & 70910259,2 & 63863142,3 \\
\hline & Potential & 4717360,57 & 7325778,59 & 6814477,83 \\
\hline & Export ratio & 0,16508023 & 0,10331056 & 0,10670439 \\
\hline \multirow[t]{3}{*}{ Zambia } & Actual & 48127449,1 & 53007107,2 & 98360680,1 \\
\hline & Potential & 53031678,5 & 85382353,2 & 71743656,7 \\
\hline & Export ratio & 1,10190088 & 1,6107718 & 0,72939366 \\
\hline \multirow[t]{3}{*}{ Zimbabwe } & Actual & 63781199,7 & 84766613,1 & 81522076,6 \\
\hline & Potential & 200898427 & 214600775 & 207429068 \\
\hline & Export ratio & 3,14980634 & 2,53166627 & 2,54445271 \\
\hline
\end{tabular}

Notes: Export ratio is computed as potential exports divided by actual exports.

Shaded cells are for countries where potential exports exceed actual exports. 